\title{
CONCEPTUAL MODEL OF RELATIONSHIPS AMONG CUSTOMER PERCEPTIONS OF COMPONENTS OF INSURANCE SERVICE
}

Urban Sebjan, Polona Tominc *

\section{Abstract}

The objective of this study was to examine the conceptual model and to study the relationships between customer perceptions of the benefits of sales promotion, quality, adequacy of premium, and adequacy of information about the coverage of insurance services. The research model was tested with structural equation modeling (SEM) with a sample of 200 Slovenian users of insurance services. The results indicated that higher perceived benefits of sales promotion were associated with higher perceived quality of insurance services. In addition, higher perceived quality was associated with higher perceived adequacy of information about the coverage and the premium for insurance services. The study also found that higher perceived adequacy of premium was associated with higher perceived adequacy of information about the coverage of insurance services.

Keywords: perceived sales promotion, perceived quality, perceived premium, perceived coverage, insurance company, insurance service

JEL classification: $G 22, M 31$

\section{INTRODUCTION}

Insurance is of great importance to a modern society since it makes an important contribution to GDP and economy (Chen et al., 2011; Kramarić and Galetic, 2013), with the Slovenian insurance market having accounted for $5.6 \%$ of GDP in 2014 (SIA, 2014). The financial crisis did not have any significant negative impact on the insurance market, as compared with its impact on the banking market (Eling and Schmeiserb, 2010), but the decline in demand for insurance products was observed in international markets, which was also detected by Slovenian insurance companies. "Increasing illiquidity, numerous corporate bankruptcies and rising unemployment have led to lower demand for several years. Insurance is a service that consumers forgo relatively quickly" (SIA, 2014, 9), so it is necessary to continuously monitor the insurance market and to explore the behavior of the users of insurance services.

The high levels of the Slovenian market's openness for foreign insurance companies enable flexible insurance penetration. Many insurance companies strive for a competitive advantage, and this is particularly the case in the area of sales promotion, which is especially important to the users of insurance services due to the combination of financial turmoil and economic

Urban Sebjan, M. Sc.

University of Maribor, Slovenia

Faculty of Economics and Business

Department of Quantitative Economics Analysis urban.sebjan@uni-mb.si

Polona Tominc, Ph.D.

University of Maribor, Slovenia

Faculty of Economics and Business

Department of Quantitative Economics Analysis, polona.tominc@uni-mb.si 
uncertainty at present. In this way, differentiated competitive relationships between insurers, whose objective is to promote sales and to maintain and increase their market share, are created in the market. With this aggressive and innovative approach, the insurance companies work to achieve the greatest benefit perceived by their customers in terms of sales promotion (price discounts, prize competitions, promotional materials, etc.).

Promotional activity has become increasingly common in the service industry (Tsao and Sheen, 2012) and has constituted an increasing proportion of promotional budgets (Laroche et al., 2001). Sales promotion has one of the strongest impacts on the shortterm consumption behavior of customers (Laroche et al., 2003). Researchers of sales promotion put their main focus on individual tools (Kumar et al., 2004; Darke and Chung, 2005; Harmon and Hill, 2003) and tend to neglect the perception of sales promotion as a whole. This is because organizations do not consider and apply sales promotion tools in an integrated and comprehensive way. In studies of sales promotion, researchers often tend to restrict themselves to price discounts, which are perceived as negatively associated with the perception of the quality of brands and products (DelVecchio and Puligadda, 2012). Despite the widespread use of promotions in marketing practice and equivocal research findings, there has been no research on determining the nature of the relationship between sales promotion and quality of service. In the intense competition of insurance companies and related insurance service offers, many users expect benefits from insurance companies, which they connect to higher perceived quality of insurance services. In the field of health insurance it was established that the perceived quality of insurance service and coverage were important factors for users' decisions to change their health insurance company (Šebjan and Bastič, 2013).

Selecting an insurance company involves the provision of adequate insurance coverage and social/ financial security by paying insurance premiums. Increasing numbers of demanding users expect a higher quality of insurance services when selecting insurance coverage and paying premiums. Because insurance coverage is complex, customers need adequate and detailed information (Eckardt and RathkeDöppner, 2010). Walker and Baker (2000) came to the conclusion that one crucial element of insurance quality is insight into the customers' expectations because they are standards for the measurement of service performance. Therefore, high quality in the process of services delivery, including adequate and detailed information for customers in the process of purchasing insurance services, has become an indispensable factor for success and survival in today's competitive insurance environment (Kumar and Singh, 2010).

A fourth component included in this research (besides perceived quality of insurance service, benefits from sales promotion and adequacy of information regarding insurance coverage) was perceived adequacy of the premium (price) of the insurance service. Most researchers have focused on studying the impact of relative price and quality on customer value and willingness to buy (Beneke et al., 2013), and only a few have studied the impact of quality on price (Bezenić, 2006).

Incorporating all of these components, the objectives of the research were to analyze (1) the impact of perceived benefits of sales promotion on perceived quality of insurance services; (2) the impact of perceived quality of insurance services on perceived adequacy of insurance services premiums; (3) the impact of perceived quality of insurance services on perceived adequacy of information about the coverage of insurance services; and (4) the impact of perceived adequacy of insurance services premiums on perceived adequacy of information about the coverage of insurance services. Additionally, the measurement scales for multidimensional variables for perceived benefits of sales promotion and perceived adequacy of information about the coverage of insurance services were developed.

\section{THEORETICAL BACKGROUND}

The purpose of the conceptual model is to reveal relationships between the perceived benefits of sales promotion, perceived quality, perceived adequacy of premium and perceived adequacy of information about the coverage of insurance services (see Figure 1).

Sales promotions can offer many customer benefits, the most obvious being monetary savings, although customers may also be motivated by the desire for quality, convenience, value expression, exploration and entertainment (Babin et al., 1994; Hirschman and Holbrook, 1982). Sales promotions provide utilitarian benefits such as monetary savings, added value, convenience and increase of quality (Weng and de Run, 2013). This is because they help customers increase the acquisition utility of their purchase and enhance the efficiency of the shopping experience (Chandon et al., 2000). Quality benefits derived from customer value can be understood as promotions relaxing budgetary constraints so that customers can afford to upgrade to higher quality products, which are otherwise too expensive to buy (Jamal et al., 2012). Because researchers have different views about the relationship 
between sales promotion tools and perceived quality, one can hypothesize that:

H1. The higher the perceived benefits of sales promotion of insurance services, the higher on average is the customer's perceived quality of insurance services.

Price is closely linked to the quality of service. If users receive the expected service compared to the money spent, they are content and feel loyal to the organization (Nusair et al., 2010; Ganguli and Roy, 2010). Price can significantly affect the perceived quality of the product/service (Zeithaml and Bitner, 2000; Chapman and Wahlers, 1999; Sanjeev and Kenneth, 2002). The perceived quality of the product/service can also have an effect on customer perceived price (Alhabeeb, 2002). Users often understand higher prices as higher quality and low prices as a result of low quality (Rao and Monroe, 1988). Since services are intangible, their price is a signal of their quality. Price becomes an important substitute for quality of service. Therefore, inexpensive services are perceived as poor in quality, while expensive services are considered as higher in quality (Verma, 2012). Benazić (2006) found that improvements in the service quality features that are subjectively evaluated as important should lead to the client's acceptance of a higher life insurance premium. Perception of the relationship between price and quality has a direct impact on perception of price and, consequently, satisfaction with price (Matzler et al., 2006). Insurance industry researchers often associate the insurance premium with the insurance coverage or insurance risk. An insurance premium is the total price of the coverage (Williams et al., 1998). Changes in insurance premium may also be reflected in changes of insurance coverage. For the customers to understand and perceive the insurance coverage appropriately, they expect quality performance from employees in terms of their physical appearance, professionalism and skill, clear explanation regarding the whole scope of insurance services, their ability to perform the promised insurance service correctly and accurately, their availability and promptness to help customers, transparent implementation and beneficial coverage from insurance services. Many of these characteristics are derived from the SERVQUAL service quality framework (Parasuraman et al., 1988), which has necessary components in the customer's perception of insurance coverage. Based on the theoretical principles, the following hypothesis is offered:

H2. The higher the perceived quality of insurance services, the higher on average is the customer's perceived adequacy of the premium of insurance service.
Perception of service quality is unders tood as a comparison between consumers' expectations and their perceptions of the services they actually receive (Grönroos, 1984; Parasuraman et al., 1985). Perceived service quality results from customers' comparison of the service they perceive that they have received against what they had expected to receive (Lovelock and Wright, 2002). The researchers focused on consumers' perceived quality of life insurance services (Siddiqui and Sharma, 2010), which was validated by a six-dimension instrument involving assurance, personalized financial planning, competence, corporate image, tangibles and technology. Sandhu and Bala (2011) developed a seven-factor construct of consumers' perceived quality of life insurance services representing proficiency: media and presentations, physical and ethical excellence, service delivery process and purpose, security and dynamic operations, credibility and functionality. Insurance service quality depends to a large extent on the information gathering and processing activities of the individual intermediaries, independent of the respective distribution channel (Eckardt and Räthke-Döppner, 2010). Gera (2011) discovered that agents selling insurance services must have in-depth knowledge and information about insurance services (besides other key attributes such as empathy, reliability and trust) that also have a significant effect on recommendation intentions. Therefore, it could be expected that customers' perception of insurance service quality are associated with a customer's satisfaction with the quality of information that he/she received in the purchasing process. Based on this discussion, we developed the followed hypotheses.

H3. The higher the perceived quality of insurance services, the higher on average is the customer's perceived adequacy of information about the coverage of insurance service.

The price of insurance coverage is denoted as the insurance premium. The premium is the money paid by the insured to the insurer for the insurance granted under a policy (Gulati, 2007). The premium is a payment made to the insurance company received from a customer in exchange for a promise to pay damages or the sum insured, the price at which the insurance company assumes the burden of risk (Flis, 1999). These premiums create a pool of money that the insurer invests to earn more money, which is used to compensate the insured for their losses (Crews, 2010). But the premium must not be equated with the price of insurance because the premium includes expected losses, which are distributed back to the insured 
(Zweifel and Eisen, 2012). There are two differences between insurance pricing and the pricing function in other industries. First, the price for insurance is based on a prediction. Second, insurance rates are subject to government regulations (Vaughan and Vaughan, 2008). Researchers have found that insurance premium is important as the determinant of demand for private health insurance (Costa and Garcia, 2003; Šebjan and Bastič, 2013). The research on the evaluation of experts' opinions has indicated that when consumers are already inclined to purchase insurance services, the impact of the price and the quality of insurance services on the final decision making are unequal: consumers give a relatively higher importance to the insurance service price (Ulbinaite and Kucinskiene, 2013).
Insurance markets are characterized by incomplete and asymmetric information between insurance companies and consumers (Cummins and Doherty, 2006). Because insurance coverage is complex, consumers need information about their risks, insurance products and contract designs (Eckardt and Räthke-Döppner, 2010). Thus, we hypothesize:

H4. The higher the perceived adequacy of premium of insurance service, the higher on average is the customer's perceived adequacy of information about the coverage of insurance service.

The conceptual model which integrates the hypothesized relationships appears in Figure 1.

Figure 1: Conceptual model

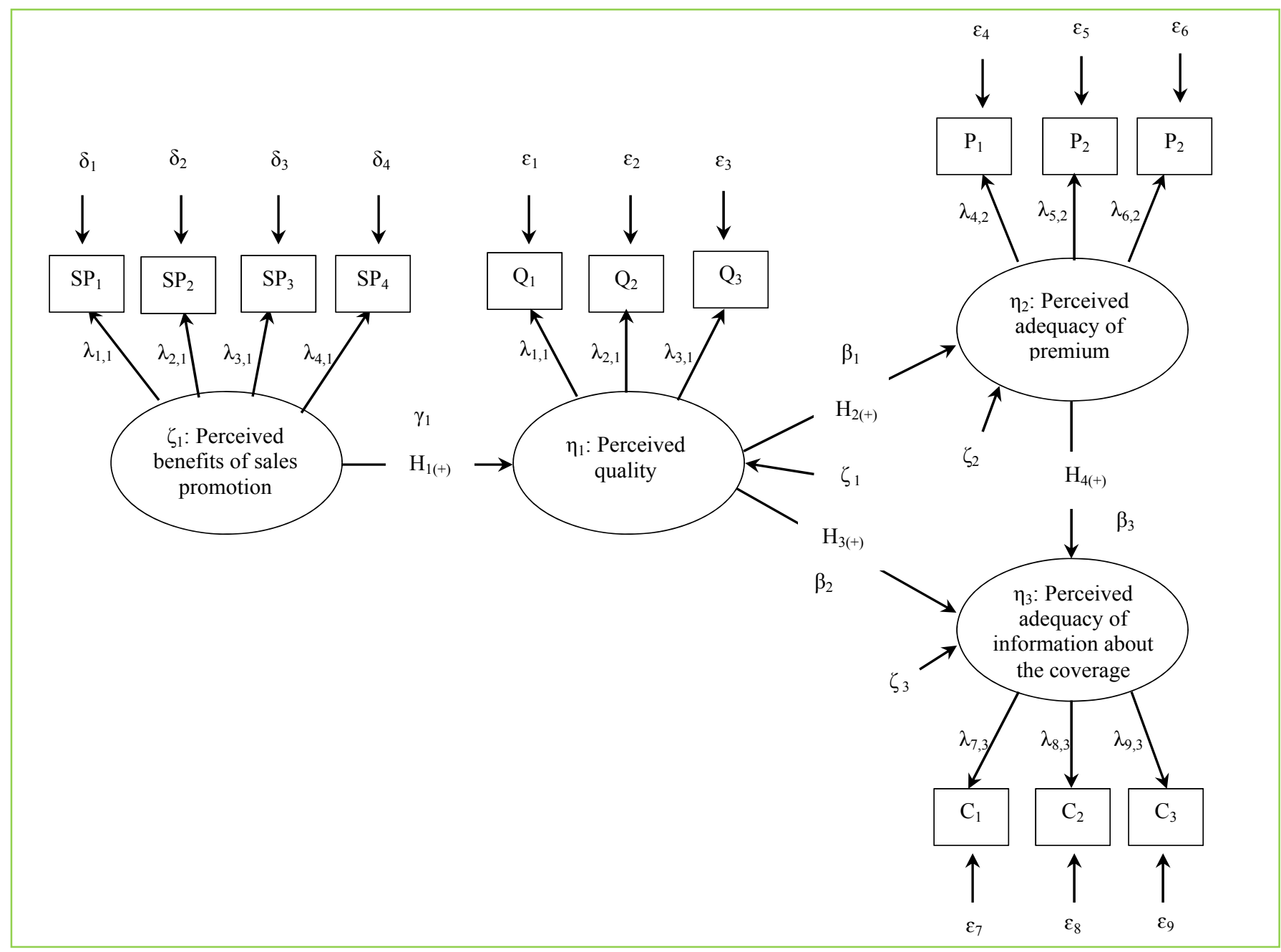

Source: Author's illustrations

Notes: $\mathrm{SP}_{1}-\mathrm{SP}_{4}$ : indicators of perceived benefits of sales promotion; $\mathrm{Q}_{1}-\mathrm{Q}_{3}$ : indicators of perceived quality; $\mathrm{P}_{1}-\mathrm{P}_{3}$ : indicators of perceived adequacy of premium; $C_{1}-C_{3}$ : indicators of perceived adequacy of information about the coverage; $\xi$ : exogenous variables; $\eta$ : endogenous variables; $\delta$ : errors for indicators of exogenous variables; $\varepsilon$ : errors for indicators of endogenous variables; $\zeta$ : errors in equations; $\lambda$ : factor loading; $\gamma$ : relationship between exogenous and endogenous latent variables; $\beta$ : relationship between endogenous latent variables and corresponding subscripts; $\mathrm{H}_{1}-\mathrm{H}_{4}$ : hypotheses. 


\section{METHODOLOGY}

\subsection{Survey instrument}

The survey measurement instrument was developed in three steps. In the first step, the questionnaire used in this study was designed according to related literature, and users' and experts' opinions. In the second step, the questionnaire was pre-tested and revised to ensure content validity. The questionnaire was reviewed by ten employees in the management of one of the Slovenian insurance companies. In this way, the questionnaire was redefined and improved. In the third step, the questionnaire was tested on a sample of five users. The questionnaire was composed of two sections. The first section intended to gain insight on each respondent's basic personal data and usage of insurance services. The second section measured the respondent's perception of each construct in the research model. The questionnaire examined the perceived benefits of sales promotion of insurance services ( 4 items), perceived quality of insurance services (27 items), perceived adequacy of premium of insurance services ( 3 items) and perceived adequacy of information about the coverage of insurance services (3 items). Perceived quality of insurance services was measured using the modified questionnaire items of Chen et al. (2012), Yoo and Park (2007) and Harris and Goode (2004). To measure the perceived adequacy of premium of insurance services, the Walsh et al. (2013), Chi and Kilduff (2011) scales were used. Since there are no scales developed for measuring the perceived benefits of sales promotion and perceived adequacy of information about the coverage, the measurement scales were developed by the authors. The final questionnaire included 37 items. All items were assessed using a five-point Likert scale from $1=$ "strongly disagree" to $5=$ "strongly agree".

\subsection{Data collection}

The target population represented random users who were legally able to buy insurance services in Slovenia, aged 18 years and older. All returned online questionnaires were correctly completed. For hypothesis testing, data was collected based on a convenience non-random sample of 200 customers of insurance services from Slovenia. At the time of the implementation of this research, a total of 23 Slovenian and foreign insurance companies operated in Slovenia (SIA, 2009). In terms of demographics, $46 \%$ were male $(n=$ 92 ) and $54 \%$ female $(n=108)$.

The largest group of respondents were from 36 to
45 years old (40\%), followed by those who were from 26 to 35 years old (24\%) and respondents who were from 46 to 55 years old (18\%). The smallest group of respondents was 66 years and older $(2 \%)$. The characteristics of the sample respondents are seen in Table 1.

Table 1. Sample characteristics

\begin{tabular}{|l|r|r|}
\hline Characteristics & Frequency & Ratio (\%) \\
\hline Gender & & \\
\hline Male & 92 & 45.9 \\
Female & 108 & 54.1 \\
\hline Education & & \\
\hline Grade school or below & 15 & 7.6 \\
Vocational school & 48 & 24.2 \\
Secondary school & 80 & 40.1 \\
College and over & 57 & 28.0 \\
\hline Age & & \\
\hline 18 to 25 & 18 & 8.9 \\
26 to 35 & 48 & 24.2 \\
36 to 45 & 80 & 40.1 \\
46 to 55 & 37 & 18.5 \\
56 to 65 & 13 & 6.4 \\
66 and over & 4 & 1.9 \\
\hline Monthly financial income & & \\
\hline Below 300 EUR & 22 & 10.8 \\
301 to 700 EUR & 64 & 31.8 \\
701 to 1.100 EUR & 66 & 33.1 \\
1.001 to 1400 EUR & 41 & 20.4 \\
1.401 EUR and over & 7 & 3.8 \\
\hline
\end{tabular}

Source: Authors' calculations

\subsection{Methods of analysis}

Statistical Package for the Social Sciences (SPSS) and Analysis of Moment Structures (AMOS) software were used to analyze the reliability and validity of the data and to conduct structural equation modeling (SEM). The analysis of the data set was based on exploratory factor analysis (EFA) and confirmatory factor analysis (CFA). Results within EFA were assessed based on the following rules: factor loadings of each item must exceed 0.5; and item-total correlation coefficients (CITC) for each item must exceed 0.5 to guarantee the reliability and validity of the questionnaire scale (Nunnally, 1978). EFA was also used to establish a scale dimensionality by checking the factorial structure of items (indicators). The Bartlett's Test of Sphericity (BTS) and the Kaiser-Meyer-Olkin statistics (KMO) were calculated. The independence of the factors and simpler factor 
structure were obtained with the analysis of principal component analysis and the varimax method.

CFA was used to ascertain the efficiency of the measurement models, and SEM was used to test the conceptual framework and assumptions. To test the model, the following rules were applied. First, the goodness of fit index (GFI), normed fit index (NFI), comparative fit index (CFI) and Tucker-Lewis index (TLI) should exceed 0.9 (Jöreskog and Sörbom, 2002; Bentler, 1990; Schumacker and Lomax, 2004). Second, the root mean residual (RMR) and the root mean square error of approximation (RMSEA) should be less than 0.05 (Jöreskog and Sörbom, 2002; Bentler, 1990) or the limit value should be less than 0.08 (Byrne, 2001). Finally, the ratio of chi-square values to freedom degrees ( $2 / \mathrm{df}$ ) should be less than 3.0 (Hoxmeier et al., 2000).

The scale reliability was assessed by item reliability measured by the individual reliability coefficient $\mathrm{R}^{2}$. $\mathrm{R}^{2}$ values above 0.5 provide evidence of acceptable reliability (Bollen, 1989). Measure reliabilities were assessed by calculating Cronbach's alpha (Cronbach, 1951) and item total correlation analysis. The majority of measures employed in this study exhibited reliability scores over 0.7 , which is above the acceptable level (Nunnally, 1978; de Vaus, 1995). Scale validity was analyzed by focusing on convergent validity, discriminant validity and nomological validity. Convergent validity is the extent to which the individual items of a construct share variance between them and was assessed in two ways (Hair et al., 2010). It was tested by checking the values of composite reliability coefficients (CR) and average variance extracted (AVE). CR should be greater than 0.7, and AVE should be greater than 0.5 (Hair et al., 2010). Discriminant validity, which examines whether the constructs are uni-dimensional, was assessed by comparing the maximum shared variance (MSV) and average shared variance (ASV). Both should be less than the average variance extracted (AVE) to establish the discriminant validity (Hair et al., 2010). Nomological validity is established when the correlations between the construct in question and theoretically related constructs are significantly greater than zero (Campbell, 1960).

\section{RESULTS}

\section{1 Validity and reliability analysis}

In the first step, exploratory factor analysis (EFA) was employed. The CITC analyses were performed for the scale of 37 items. All cut-off values of 37 items were higher than 0.5. EFA showed that tree constructs were one-dimensional and one construct was threedimensional (perceived quality of insurance service). The principle axing factoring extraction method was applied with varimax rotation (Anderson and Gerbing, 1988). Following the recommendation of Hair et al. (2010), all items had standardized factor loadings higher than 0.5. The Kaiser-Meyer-Olkin (KMO) value was 0.944 , which was more than the recommended value of 0.5 for sample adequacy. Bartlett's test of sphericity (BTS $=5327.684)$ was also significant $(\mathrm{p}<$ 0.001). Factors with Eigenvalues greater than 1 and factor loading greater than 0.50 were retained for further analysis. A four-factor solution (perceived sales promotion, perceived premium, perceived quality and perceived coverage of insurance service) with 37 items was chosen.

In the next step, the scale's psychometric properties were evaluated using confirmatory factor analysis (CFA). Four factors were created and used as latent variables. Convergent validity was assessed by examining the loadings and their statistical significance through $t$-values (Dunn et al., 1994). Item factor loadings were very high, ranging from 0.719 to 0.922 ; all were significant at the 0.001 level. The $\mathrm{R}^{2}$ values were used to estimate the reliability of particular observed items. An examination of their values reveals that all items did meet the 0.5 criterion. The items of the final scales with their loadings, item-total correlations, percentages of explained variance, item reliability, means and standard deviations are presented in Table 2. The "perceived benefits of sales promotion of insurance services" factor explained $59.7 \%$ of total variance; "perceived adequacy of premium of insurance services" explained $10.2 \%$; "perceived adequacy of information about the coverage of insurance service" explained $6.1 \%$; and "perceived quality of insurance service" explained $5.3 \%$. These four factors accounted for $81.2 \%$ of the total variance.

Construct reliability means that a set of construct items is consistent in its measurement. For the constructs, the composite reliability (CR) and the average variance extracted (AVE) were computed. Table 3 shows the construct reliability for all four constructs: perceived benefits from sales promotion of insurance services $\left(\rho_{c}{ }^{\mathrm{CR}}=0.916, \rho_{c}{ }^{\mathrm{AVE}}=0.732\right)$; perceived quality of insurance company $\left(\rho_{c}{ }^{\mathrm{CR}}=0.900, \rho_{c}^{\mathrm{AVE}}=0.750\right)$; perceived adequacy of premium of insurance services $\left(\rho_{c}{ }^{C R}=0.874, \rho_{c}{ }^{A V E}=0.698\right) ;$ and perceived adequacy of information about the coverage of insurance service $\left(\rho_{c}{ }^{\mathrm{CR}}=0.840, \rho_{c}{ }^{\mathrm{AVE}}=0.637\right)$. The $\mathrm{CR}$ and AVE for all four constructs surpassed the threshold values of 0.7 and 0.5 , respectively (Hair et al., 1998). The internal 
Table 2. Factors and items, factors loading, variance explained, item reliabiliwwty, mean and standard deviation

\begin{tabular}{|c|c|c|c|c|c|c|c|}
\hline Constructs & Items & $\begin{array}{l}\text { Item-total } \\
\text { correlation }\end{array}$ & $\begin{array}{l}\text { Factors } \\
\text { loading }^{\text {a }}\end{array}$ & $\begin{array}{l}\text { Variance } \\
\text { explained }\end{array}$ & $\begin{array}{l}\mathrm{R}^{2} \text { (item } \\
\text { reliability) }\end{array}$ & Mean $^{b}$ & $\begin{array}{l}\text { Standard } \\
\text { deviation }\end{array}$ \\
\hline \multirow{4}{*}{$\begin{array}{l}\text { Perceived } \\
\text { benefits of } \\
\text { sales pro- } \\
\text { motion of } \\
\text { insurance } \\
\text { services }\end{array}$} & $\begin{array}{l}\text { SP1 - The insurance company } \\
\text { always delivers me promotional } \\
\text { material when buying the insur- } \\
\text { ance policy. }\end{array}$ & 0.809 & 0.827 & \multirow{4}{*}{59.731} & 0.685 & 3.31 & 1.254 \\
\hline & $\begin{array}{l}\text { SP2 - Additional promotion } \\
\text { benefits are beneficial and } \\
\text { useful. }\end{array}$ & 0.776 & 0.802 & & 0.643 & 3.54 & 0.957 \\
\hline & $\begin{array}{l}\text { SP3 - The insurance company } \\
\text { offers different educational } \\
\text { events and presentations. }\end{array}$ & 0.819 & 0.881 & & 0.775 & 3.23 & 1.176 \\
\hline & $\begin{array}{l}\text { SP4 - The insurance company } \\
\text { offers participation in sweep- } \\
\text { stakes and other prize games. }\end{array}$ & 0.829 & 0.890 & & 0.792 & 3.11 & 1.207 \\
\hline \multirow{3}{*}{$\begin{array}{l}\text { Perceived } \\
\text { adequacy } \\
\text { of premium } \\
\text { of insurance } \\
\text { services }\end{array}$} & $\begin{array}{l}\text { P1 - The insurance coverage is } \\
\text { clearly evident from the premi- } \\
\text { um paid. }\end{array}$ & 0.796 & 0.865 & \multirow{3}{*}{10.169} & 0.749 & 3.64 & 0.817 \\
\hline & $\begin{array}{l}\text { P2 - Insurance company offers } \\
\text { different ways of payment. }\end{array}$ & 0.742 & 0.818 & & 0.669 & 3.73 & 0.812 \\
\hline & $\begin{array}{l}\text { P3 - Premium of insurance ser- } \\
\text { vice is justified by the service } \\
\text { provided. }\end{array}$ & 0.716 & 0.822 & & 0.675 & 3.62 & 0.996 \\
\hline \multirow{3}{*}{$\begin{array}{l}\text { Perceived } \\
\text { adequacy } \\
\text { of informa- } \\
\text { tion about } \\
\text { coverage of } \\
\text { insurance } \\
\text { services }\end{array}$} & $\begin{array}{l}\text { C1 - The insurance coverage is } \\
\text { clearly and exactly evident from } \\
\text { the insurance policy. }\end{array}$ & 0.714 & 0.719 & \multirow{3}{*}{6.056} & 0.517 & 3.75 & 0.933 \\
\hline & $\begin{array}{l}\text { C2 - The insurance company } \\
\text { provides me with detailed in- } \\
\text { formation about the insurance } \\
\text { coverage. }\end{array}$ & 0.782 & 0.797 & & 0.635 & 3.69 & 0.965 \\
\hline & $\begin{array}{l}\text { C3 - The insurance company } \\
\text { has made available a lot of ad- } \\
\text { equate coverage that meet my } \\
\text { needs. }\end{array}$ & 0.713 & 0.871 & & 0.759 & 3.64 & 0.914 \\
\hline \multirow{3}{*}{$\begin{array}{l}\text { Perceived } \\
\text { quality of } \\
\text { insurance } \\
\text { services }^{c}\end{array}$} & Q1 - Quality of offer & 0.829 & 0.922 & \multirow{3}{*}{5.265} & 0.850 & 3.86 & 0.737 \\
\hline & Q2 - Quality of employees & 0.836 & 0.896 & & 0.802 & 3.76 & 0.760 \\
\hline & $\begin{array}{l}\text { Q3 - Quality of implementation } \\
\text { services }\end{array}$ & 0.736 & 0.760 & & 0.577 & 3.95 & 0.669 \\
\hline
\end{tabular}

Source: Authors' calculations

Notes: ${ }^{a}$ All factors loadings are significant at 0.001 level, ${ }^{b}$ Measured on a five-point scale, ranging from $1=$ strongly disagree to $5=$ strongly agree, ${ }^{c}$ Composite indicator.

consistency of the items in relation to the single trait within the instrumental was tested using Cronbach's a, ranging from 0.861 to 0.913 .

All values were above the generally agreed-upon lower limit of 0.7, indicating high internal consistency among the variables within each factor (Nunnally, 1978). The convergent validity of the measurement model was completely confirmed. Following Fornell and Locker's (1981) approach for evaluating discriminant validity, the average variance extracted (AVE) and squared correlation for every possible pair of factors were compared. The discriminant validity of the measurement model was partially confirmed. Two values of maximum shared variance (MSV) are less than AVE (perceived benefits of sales promotion and perceived quality of insurance services). All values of average shared variance (ASV) are less than AVE (see Table 3). The results indicate that the model partially 
Table 3. Convergent and discriminant validity of measurement models

\begin{tabular}{|c|c|c|c|c|c|c|c|}
\hline Construct & $\begin{array}{c}\text { Cronbach's } \\
\alpha \alpha\end{array}$ & $\mathrm{CR}^{\mathrm{a}}$ & $\operatorname{AVE}^{b}$ & $\mathrm{MSV}^{\mathrm{c}}$ & ASV $^{d}$ & $\begin{array}{c}\text { Results of } \\
\text { convergent } \\
\text { validity } \\
\text { CR }>\text { AVE } \\
\text { AVE }>0.5\end{array}$ & $\begin{array}{c}\text { Results of } \\
\text { discriminant } \\
\text { validity } \\
\text { MSV }<\text { AVE } \\
\text { ASV }<\text { AVE }\end{array}$ \\
\hline $\begin{array}{l}\text { Perceived benefits of sales promo- } \\
\text { tion of insurance company }\end{array}$ & 0.913 & 0.916 & 0.732 & 0.531 & 0.474 & yes & yes \\
\hline $\begin{array}{l}\text { Perceived quality of insurance } \\
\text { company }\end{array}$ & 0.897 & 0.900 & 0.750 & 0.686 & 0.611 & yes & yes \\
\hline $\begin{array}{l}\text { Perceived adequacy of premium } \\
\text { of insurance service }\end{array}$ & 0.865 & 0.874 & 0.698 & 0.712 & 0.573 & yes & partially \\
\hline $\begin{array}{l}\text { Perceived adequacy of informa- } \\
\text { tion about the coverage of insur- } \\
\text { ance service }\end{array}$ & 0.861 & 0.840 & 0.637 & 0.712 & 0.632 & yes & partially \\
\hline
\end{tabular}

Source: Authors' calculations

Notes: ${ }^{a}$ CR refers to the composite reliability $\left(\rho_{\mathrm{c}}=\left(\Sigma \lambda_{\mathrm{i}}\right)^{2} \operatorname{var}(\xi) /\left[\left(\Sigma \lambda_{\mathrm{i}}\right)^{2} \operatorname{var}(\xi)+\Sigma \theta_{\mathrm{ii}}\right] ;\right.$ (Bagozzi and Yi, 1998)), ${ }^{\mathrm{b}}$ AVE refers to the average variance extracted $\left(\rho_{\mathrm{c}}=\left(\Sigma \lambda_{\mathrm{i}}{ }^{2} \operatorname{var}(\xi)\right) /\left[\Sigma \lambda_{\mathrm{i}}^{2} \operatorname{var}(\xi)+\Sigma \theta_{\mathrm{ii}}\right]\right.$; (Fornell and Larcker, 1981)), ${ }^{\mathrm{C}} \mathrm{MSV}$ refers to the maximum shared variance, ${ }^{d} \mathrm{ASV}$ refers to the average shared variance.

supported discriminant validity (AVE $>$ ASV and AVE $>$ MSV). The inter-construct correlations are all positive and significant. The values are as expected relative to direction and size, and they make sense from a theoretical point of view. The results indicate that the model has complete nomological validity.

\subsection{Competing model analysis}

This study utilized three types of overall model fit measures: absolute, incremental and parsimonious. In the first step, the index of fit was evaluated for the one-factor model and the tree-factor model of perceived quality insurance services. The construct of perceived quality of insurance services was measured with a large number of variables. With the help of the CFA method, a three-factor model of perceived quality insurance services was developed. The one factor model and the free-factor model of perceived quality insurance services were compared to check which model was more consistent with the data. The $\chi^{2}(17)=$ 32.461 of the measurement model was significant $(p<$ 0.05). The Root Mean Square Error of Approximation (RMSEA) and the Root Mean Square Residual (RMR) values were 0.076 and 0.020 , indicating a good model fit. The goodness-of-fit index (GFI) and the normed Fit Index (NFI), which were equal to 0.952 and 0.966 , were above the threshold value of 0.9. The Relative Fit Index (RFI) reached a value of 0.943 and the Incremental Fit Index (IFI = 0.983). Both indices were above the threshold value of 0.9 . The other fit indices achieved the recommended value of 0.9 (the Comparative Fit Index CFI $=0.983$ and the Tucker-Lewis Index TLI = $0.972)$. A significant chi-square value $\left(\chi^{2} / \mathrm{df}=1.909\right)$ indicated that the model did not fit the data perfectly. The results indicated that the three-factor model of perceived quality insurance services was much more valid than the one-factor model (see Table 4).

Table 4. Summary statistics for one-factor and multi-factor models for perceived quality of insurance services

\begin{tabular}{|l|l|l|}
\hline Construct & \multicolumn{1}{|c|}{$\begin{array}{c}\text { One-factor } \\
\text { model }\end{array}$} & \multicolumn{1}{c|}{$\begin{array}{c}\text { Multi-factor } \\
\text { model }\end{array}$} \\
\hline & $\begin{array}{l}1 \text { factor } \\
\chi^{2}(20)=53.446\end{array}$ & $\begin{array}{l}\text { factors* } \\
\chi^{2}(17)=32.461\end{array}$ \\
& $\chi^{2} / \mathrm{df}=2.672$ & $\chi^{2} / \mathrm{df}=1.909$ \\
& $p=0.000$ & $p=0.013$ \\
Perceived & $\mathrm{RMSEA}=0.104$ & $\mathrm{RMSEA}=0.076$ \\
quality of & $\mathrm{RMR}=0.029$ & $\mathrm{RMR}=0.020$ \\
insurance & $\mathrm{GFI}=0.921$ & $\mathrm{GFI}=0.952$ \\
services & $\mathrm{TLI}=0.949$ & $\mathrm{TLI}=0.972$ \\
& $\mathrm{CFI}=0.963$ & $\mathrm{CFI}=0.983$ \\
& $\mathrm{NFI}=0.943$ & $\mathrm{NFI}=0.966$ \\
& $\mathrm{RFI}=0.921$ & $\mathrm{RFI}=0.943$ \\
& $\mathrm{IFI}=0.964$ & $\mathrm{IFI}=0.983$ \\
\hline
\end{tabular}

Source: Authors' calculations

Notes: *Multifactorial model: quality of offer, quality of employees and quality of implementation services. 
In the second step, the fit indices were evaluated for the one-factor and four-factor models of complete conceptual model. The one-factor model and four-factor models of the complete conceptual model were compared to evaluate the consistency of each of the models with the data. The four-factor model was developed with the CFA method. The results of the index of fit indicated that the four-factor model was much more valid than the one-factor model (see Table 5). The $\chi^{2}(58)=101.579(p=0.000)$ of the measurement models was significant $(p<0.001)$. The goodness-offit index (GFI) and the Normed Fit Index (NFI), which were equal to 0.912 and 0.939 , were above the threshold value of 0.9. The Relative Fit Index (RFI) and the Incremental Fit Index (IFI) were assessed, with values of 0.918 and 0.973 . Both indices were above the threshold value of 0.9. The Comparative Fit Index (CFI) and the Tucker-Lewis Index (TLI) were also assessed, with values of 0.972 and 0.963 , respectively, both above the recommended level of 0.9 , indicating support for the proposed model. The RMSEA, the RMR and the normed $\chi^{2}$ were calculated to test parsimonious fit. The RMSEA and RMR values were 0.069 and 0.035 , indicating a good model fit. Moreover, the normed $\chi^{2}\left(\chi^{2} / \mathrm{df}=1.751\right)$ fell between 1 and 2 , further indicating a parsimonious fit. Hence, the suggested factorial structure fit properly.

Table 5. Summary statistics for one-factor and multi-factor of conceptual models

\begin{tabular}{|l|l|}
\hline $\begin{array}{l}\text { One-factor } \\
\text { model }\end{array}$ & $\begin{array}{l}\text { Multi-factor } \\
\text { Model }\end{array}$ \\
\hline 1 factor & 4 factors* \\
$\chi^{2}(64)=373.363$ & $\chi^{2}(58)=101.579$ \\
$\chi^{2} / \mathrm{df}=5.834$ & $\chi^{2} / \mathrm{df}=1.751$ \\
$p=0.000$ & $p=0.000$ \\
$\mathrm{RMSEA}=0.176$ & $\mathrm{RMSEA}=0.069$ \\
$\mathrm{RMR}=0.088$ & $\mathrm{RMR}=0.035$ \\
$\mathrm{GFI}=0.804$ & $\mathrm{GFI}=0.912$ \\
$\mathrm{TLI}=0.762$ & $\mathrm{TLI}=0.963$ \\
$\mathrm{CFI}=0.804$ & $\mathrm{CFI}=0.972$ \\
$\mathrm{NFI}=0.775$ & $\mathrm{NFI}=0.939$ \\
$\mathrm{RFI}=0.726$ & $\mathrm{RFI}=0.918$ \\
$\mathrm{IFI}=0.806$ & $\mathrm{IFI}=0.973$ \\
\hline
\end{tabular}

Source: Authors' calculations

Notes: *Multifactorial model: perceived quality, perceived benefits of sales promotion, perceived adequacy of premium and perceived adequacy of information about the coverage.

\subsection{Hypothesis testing}

The conceptual model was examined with structural equation modeling. The overall fit measures of the full model in the SEM indicated that the fit of the model was acceptable. The indices of fit for the first development conceptual model were: $\chi^{2}(61)=115.000(p=$ $0.000), \mathrm{GFI}=0.901, \mathrm{CFI}=0.966, \mathrm{TLI}=0.956, \mathrm{RFI}=0.911$, $\mathrm{IFI}=0.966, \mathrm{NFI}=0.931, \mathrm{RMR}=0.042, \mathrm{RMSEA}=0.075$, $\chi^{2} / \mathrm{df}=1.885$. Then an improved final conceptual model was developed that allowed statistically significant correlation between errors for indicators of one construct: perceived adequacy of information about the coverage of insurance services (between C1- the insurance coverage was clearly and exactly evident from the insurance policy; and C2- the insurance company provided detailed information about the insurance coverage.). The fit indices for the improved final conceptual model were: $\chi^{2}(60)=106.392(p=0.000)$, $\mathrm{GFI}=0.909, \mathrm{CFI}=0.971, \mathrm{TLI}=0.962, \mathrm{RFI}=0.917, \mathrm{IFI}=$ $0.971, \mathrm{NFI}=0.936, \mathrm{RMR}=0.042, \mathrm{RMSEA}=0.070, \chi^{2} / \mathrm{df}$ $=1.773$. The improved final conceptual model is presented in Figure 2.

As predicted by $\mathrm{H}_{1}$, the perceived benefits of sales promotion was a significant and positive predictor of perceived quality of insurance services $\left(\gamma_{1}=0.745 ; \mathrm{t}=\right.$ 10.093; $p<0.001)$. Perceived benefits of sales promotion had a positive and strong influence on perceived quality of insurance services.

Hypothesis $\mathrm{H}_{2}$ predicted that perceived quality of insurance services was positively related to perceived adequacy of premium of insurance services. The results show that the perceived quality of insurance services was indeed significantly positive and strongly related to perceived adequacy of the premium $\left(\beta_{1}\right.$ $=0.790 ; \mathrm{t}=10.599 ; p<0.001)$ of insurance services. The findings supported hypothesis $\mathrm{H}_{2}$. As hypothesis $\mathrm{H}_{3}$ predicted, perceived quality of insurance services is significantly related to perceived adequacy of information about the coverage of insurance services. Perceived quality of insurance services had a positive and significant influence on perceived adequacy of information about the coverage of insurance services $\left(\beta_{2}=0.469 ; t=4.217 ; p<0.001\right)$.

The findings therefore supported hypothesis $\mathrm{H}_{3}$. The findings of the model testing also supported $\mathrm{H}_{4}$ $\left(\beta_{3}=0.473 ; t=3.943 ; p<0.001\right)$ and therefore confirmed that perceived adequacy of premium of insurance services had a positive and significant influence on perceived adequacy of information about the coverage of insurance services. Therefore, $\mathrm{H}_{1}, \mathrm{H}_{2}, \mathrm{H}_{3}$ and $\mathrm{H}_{4}$ were all supported in this study. Table 6 shows the results of the structural model in this study. 
Figure 2. Improved final conceptual model

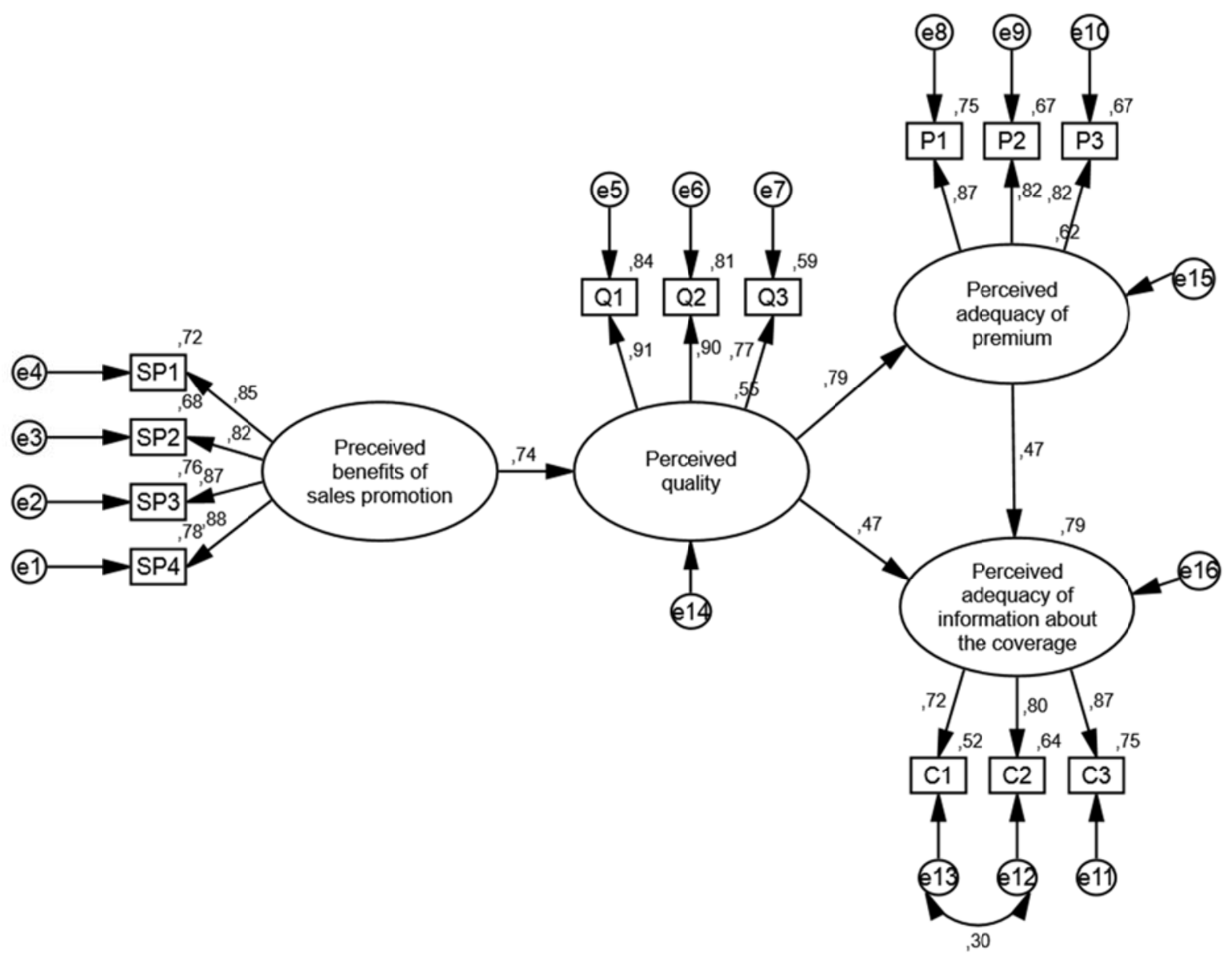

Source: Author's illustrations

Notes: $Q_{1}-Q_{3}$ : indicators of perceived quality; $P_{1}-P_{3}$ : indicators of perceived adequacy of premium; $C_{1}-C_{3}$ : indicators of perceived adequacy of information about the coverage. Fit indices: $\chi^{2}(60)=106.392(p=0.000), \mathrm{GFI}=0.909, \mathrm{CFI}=0.971, \mathrm{TLI}=$ $0.962, \mathrm{RFI}=0.917, \mathrm{IFI}=0.971, \mathrm{NFI}=0.936, \mathrm{RMR}=0.042, \mathrm{RMSEA}=0.070, \chi^{2} / \mathrm{df}=1.773$.

Table 6. Estimated effects within the causal model

\begin{tabular}{|l|c|c|c|c|l|}
\hline Structural relationship & $\begin{array}{c}\text { Standardized } \\
\text { regression } \\
\text { coefficient }\end{array}$ & $\begin{array}{c}\text { Standard } \\
\text { error }\end{array}$ & t-value & Significance & Results \\
\hline $\begin{array}{l}\mathrm{H} 1: \text { Perceived benefits of sales promotion } \\
\rightarrow \text { perceived quality of insurance services }\end{array}$ & $\gamma_{1}=0.745$ & 0.047 & 10.093 & $p<0.001$ & $\begin{array}{l}\mathrm{H} 1 \text { is } \\
\text { supported }\end{array}$ \\
\hline $\begin{array}{l}\mathrm{H} 2: \text { Perceived quality of insurance services } \\
\rightarrow \text { perceived adequacy of premium of insur- } \\
\text { ance service }\end{array}$ & $\beta_{1}=0.790$ & 0.078 & 10.599 & $p<0.001$ & $\begin{array}{l}\mathrm{H} 2 \text { is } \\
\text { supported }\end{array}$ \\
\hline $\begin{array}{l}\mathrm{H} 3: \text { Perceived quality of insurance services } \\
\rightarrow \text { perceived adequacy of information about } \\
\text { the coverage of insurance service }\end{array}$ & $\beta_{2}=0.469$ & 0.131 & 4.217 & $p<0.001$ & $\begin{array}{l}\mathrm{H} 3 \text { is } \\
\text { supported }\end{array}$ \\
\hline $\begin{array}{l}\text { H4: Perceived adequacy of premium of insur- } \\
\text { ance service } \rightarrow \text { perceived adequacy of informa- } \\
\text { tion about the coverage of insurance service }\end{array}$ & $\beta_{3}=0.473$ & 0.135 & 3.943 & $p<0.001$ & $\begin{array}{l}\mathrm{H} 4 \text { is } \\
\text { supported }\end{array}$ \\
\hline
\end{tabular}

Source: Authors' calculations 


\section{CONCLUSION}

To sum up, the results of this study show that there is a connection between components of insurance services (perceived benefits of sales promotion, perceived quality, perceived adequacy of premium and perceived adequacy of information about the insurance coverage) and that the perception of one component is reflected in the perception of other components. The results of this research also show that the perception of the components of sales promotion by Slovenian customers is relatively low. From this, one can conclude that there is an increase in customer expectations, and that insurance companies do not invest enough in creating innovative approaches to promote sales with perceived benefits. It is important to see insurance services as a whole. For that reason, these research results should provide incentives for managers of insurance companies to consider investing their efforts and resources into the development of specific components of insurance services.

Generalization from the study results requires caution, as this study was limited to customers of insurance services in Slovenia. The study was also limited in regard to the items measuring the perceived components of insurance service (i.e. perceived benefits of sales promotion, perceived quality, perceived adequacy of the premium and perceived adequacy of information about the insurance coverage). The final limitation relates to the development of the conceptual model with components of insurance service and the relationship between them. Future research could include: (1) other components of insurance services (e.g. perceived innovation, perceived social responsibility and perceived image); (2) the difference between the conceptual models according to customers from different countries (e.g. Slovenes, Croats Austrians); (3) development of fair components of insurance and design of the conceptual model; (4) the difference between the conceptual models according to customers' demographic characteristics (e.g. education, gender, income and status); (5) the difference between the conceptual models according to customers' domestic and foreign insurance companies; (6) the difference between the conceptual models according to the scope of insurance coverage; and (7) the difference between the conceptual models according to the type of insurance (e.g. life, non-life, health and accident insurance services).

In the Slovenian insurance industry, an increase in competition was identified, especially with the emergence of new foreign insurance companies. Time based competition, quality, product range and service created a more competitive environment, but the decisive test is how competitive advantages are used by the companies to differentiate themselves (Gayathri et al., 2006). Insurance companies are actively developing components of insurance services to satisfy customer expectations. Furthermore, the developing components are most likely to create a competitive advantage for a company in insurance markets. If insurance companies are acquainted with the role of the components of insurance services, they can more easily develop insurance services. Development of insurance services components tends to be perceived as very high if the insurance staff perceives the role of components of insurance services as customers. It is important that insurance staff understand how the components of insurance services are related. For that purpose, the management of insurance companies should provide enough information for their employees (through seminars, trainings, simulations, etc.) about the implementation of different tools that contribute to higher customer perceptions of the benefits of sales promotion and other components of insurance service. It is not enough just to know about the characteristics of components of insurance services; it is also important to use such knowledge about them. How the insurance company integrates and represents these components to (prospective) customers is also important. Not only do customers prefer a large number of discounts and advantages, but they also seek discounts and advantages that are tailored for them.

Insurance companies should invest more energy in raising awareness of customers' preventive insurance and spreading information about insurance services in the form of events, brochures, websites with useful advice, and via mobile applications. Insurance companies should invest more in activities, in sustaining development of the relationship with customers in the form of personal visits by salespeople and in organizing different events and maintaining contact with their customers by email. The expectations of Slovenian customers are rather high, so an insurance company focusing on components of insurance services will definitely help increase perceived value from its customers.

\section{REFERENCES}

Alhabeeb, M.J. 2002. Perceived product quality, purchase value, and price. Academies International Conference. Academy of Marketing Studies 7 (1): 9-14.

Anderson, J., Gerbing, D.W. 1988. Structural equation modeling in practice: a review and recommended two-step approach. Psychological Bulletin 103 (3): 411-423. 
Babin, B.J., Darden, W.R., Griffin, M. 1994. Work and/or fun? Measuring hedonic and utilitarian shopping value. Journal of Consumer Research 20 (March): 644-656.

Benazić, D. 2006. Interdependence of life insurance service quality and premium. Tržište 18 (1-2): 67-80.

Beneke, Đ., Flynn, R., Greig, T., Mukaiwa, M. 2013. The influence of perceived product quality, relative price and risk on customer value and willingness to buy: a study of private label merchandise. Journal of Product \& Brand Management 22 (3): 218-228.

Bentler, P.M. 1990. Comparative fit indexes in structural models. Psychological Bulletin 107 (2): 238-246.

Bollen, K.A. 1989. Structural Equations with Latent Variables. Wiley-Interscience Publication.

Byrne, B.M. 2001. Structural Equation Modeling with AMOS. Basic Concepts, Applications and Programming. New Jersey: Lawrence Erlbaum Associates.

Campbell, D.T. 1960. Recommendations for APA test standards regarding construct, trait, or discriminant validity. American Psychologist 15 (8): 546-553.

Chandon, P., Wansink, B., Laurent, G. 2000. A benefit congruency framework of sales promotion effectiveness. Journal of Marketing 64 (4): 65-81.

Chapman, J., Wahlers, R. 1999. A revision and empirical test of the extended price-perceived quality model. Journal of Marketing Theory and Practice 7 (3), 53-64.

Chen, P.-E., Lee, C.-C., Lee, C.-F. 2011. How does the development of the life insurance market affect economic growth? Journal of International Development 27 (7): 865-893.

Chen, H.G., Liu, J.Y.C., Sheu, T.S., Yang, M.H. 2012. The impact of financial services quality and fairness on customer satisfaction. Managing Service Quality 22 (4): 399-421.

Chi, T., Kilduff, P.P.D. 2011. Understanding consumer perceived value of casual sportswear: An empirical study. Journal of Retailing and Consumer Services 18 (5): 422-429.

Costa-Font, J., Garcia, J. 2003. Demand For Private Health Insurance: How Important Is The Quality Gap?. Health Economics 12 (7): 587-599.

Crews, T. 2010. Fundamentals of Insurance. South-Western Cengage Learning: Mason.

Cronbach, L.J. 1951. Coefficient alpha and the internal structure of tests. Psychometrika 16 (3): 297-334.

Cummins, J.D.,Doherty, N.A. 2006. The Economics of Insurance Intermediaries. Journal of Risk and Insurance 73 (3): 359-396.

Darke, P.R., Chung, C.M.Y. 2005. Effects of pricing and promotion on consumer perceptions: it depends on how you frame it. Journal of Retailing 81 (1): 35-47.

DelVecchio, D., Puligadda. S. 2012. The effects of lower prices on perceptions of brand quality: a choice task perspective. Journal of Product \& Brand management 21 (6): 465-474.
Dunn, S.C., Seaker, R.F., Waller, M.A. 1994. Latent variables in business logistics research: scale development and validation. Journal of Business Logistics 15 (2): 145-172.

Eckardt, M., Räthke-Döppner, S. 2010. The Quality of Insurance Intermediary Services-Empirical Evidence for Germany. Journal of Risk and Insurance 77 (3): 667-701.

Eling, M., Schmeiserb, H. 2010. Special Issue on the Credit Crisis and Insurance. The Geneva Papers 35: 9-34.

Flis, S. 1999. Zbrani spisi o zavarovanju, Slovensko zavarovalno združenje. GIZ: Ljubljana.

Fornell, C., Lacker, D.F., 1981. Evaluating structural equation models with unobservable variables and measurement error. Journal of Marketing Research 18 (1): 39-50.

Ganguli, S., Roy, S.K. 2010. Service quality dimensions of hybrid services. Managing Service Quality 20 (5): 404-424.

Gayathri, H., Vinaya, M.C., Lakshmisha, K. 2006. A pilot study on the service quality of insurance companies. Journal of Services Research 5 (2): 123-138.

Gera, R. 2011. Modelling the service antecedents of favourable and unfavourable behaviour intentions in life insurance services in India: An SEM study. International Journal of Quality and Service Sciences 3 (2): 225-242.

Grönroos, C. 1984. A service quality model and its marketing implications. European Journal of Marketing 18 (4): 36-44.

Gulati, N.C. 2007. Principles of insurance management. Excel Books: New Delhi.

Hair, J.F., Anderson, R.E., Tatham, R.L., Black, W.C. 1998. Multivariate Data Analysis with Readings, 5th ed. New York: Prentice-Hall International, Englewood Cliffs.

Hair, J.F., Black, W.C., Babin, B.J., Anderson, R.E. 2010. Multivariate data analysis. New Jersey: Prentice Hall.

Harmon, S.K., Hill, C.J. 2003. Gender and coupon use. Journal of Product \& Brand management 12 (3): 166-179.

Harris, L.C., Goode, M.M.H. 2004. The four levels of loyalty and the pivotal role of trust: a study of online service dynamics. Journal of Retailing 80 (2): 139-158.

Hirschman, E.G., Holbrook, M.B. 1982. Hedonic consumption: emerging concepts, methods and propositions. Journal of Marketing 46 (3): 92-101.

Hoxmeier, J.A., Nie, W., Purvis, G.T. 2000. The impact of gender and experience on user confidence in electronic mail. Journal of End User Computing 12 (4): 11-21.

Hussels, S., Ward, D., Zurbruegg, R. 2005. Stimulating the Demand for Insurance. Risk Management and Insurance Review 8 (2): 257-278.

Jamal, A., Peattie, S., Peattie, K. 2012. Ethnic minority consumers' responses to sales promotions in the packaged food market. Journal of Retailing and Consumer Services 19 (1): 98-108.

Jöreskog, K.G., Sörbom, D. 2002. LISREL 8: structural equation modeling with the SIMPLIS command language. Lincolnwood: Scientific Software International. 
Kramaric, T.P., Galetic, F. 2013. The Role of the Overall Economic Development on the Insurance Market Growth-Evidence of the European Union. Journal of Applied Finance and Banking 3 (3): 157-168.

Kumar, V., Madan, V., Srinivasan, S.S. 2004. Price discounts or coupon promotions: does it matter? Journal of Business Research 57 (9): 933-941.

Kumar, R., Singh, M. 2010. Using SERVQUAL Model for Comparative Service Quality Analysis of the Indian Nonlife Insurance Sector. Paradigm (14) 2: 1-19.

Laroche, M., Pons, F., Zgolli, N., Cervellon, M.-C., Kim C. 2001. Consumers use of price promotions: a model and its potential moderators. Journal of Retailing and Consumer Services 8 (5): 251-260.

Laroche, M., Pons, F., Zgolli, N., Cervellon, M.-C., Kim, C. 2003. A model of consumer response to two retail sales promotion, techniques. Journal of Business Research 56 (7): 513-522.

Lovelock, C., Wright, L. 2002. Principles of service marketing and management. Prentice Hall: Upper Saddle River.

Matzler, K., Würtele, A., Renzl, B. 2006. Dimensions of price satisfaction: a study in the retail banking industry. International Journal of Bank Marketing 24 (4): 216-231.

Nunnally, J. C. 1978. Psychometric Theory. Mc-Graw-Hill Book Company: New York.

Nusair, K., Yoon, H.J., Naipaul, S., Parsa, H.G. 2010. Effect of price discount frames and levels on consumers' perceptions in low-end service industries. International Journal of Contemporary Hospitality Management 22 (6): 814-835.

Parasuramanom, A., Zeithaml, V., Berry, L. 1985. A Conceptual Model of Service Quality and Its Implications for Future Research. Journal of Marketing 49 (4): 35-48.

Parasuramanom, A., Zeithaml, V., Berry, L. 1988. SERVQUAL: A Multiple Item Scale for Measuring Consumer Perceptions of Service Quality. Journal of Retailing 64 (1): 12-40.

Rao, A., Monroe, K.B. 1988. The moderating effect of prior knowledge on cue utilizations in product evaluations. Journal of Consumer Research 19 (2): 253-264.

Sandhu, H.S., Bala, N. 2011. Customers' Perception towards Service Quality of Life Insurance Corporation of India: A Factor Analytic Approach. International Journal of Business and Social Science 2 (18): 219-231.

Sanjeev, A., Kenneth, T.R. 2002. Cross-national applicability of a perceived quality model. The Journal of Product and Brand Management 11 (4/5): 213-236.

Schumacker, R.E., Lomax, R.G. 2004. A beginner's guide to structural equation modeling. London: L. Erlbaum.

SIA - Slovenian Insurance Association. Statistical Insurance Bulletin 2009. 2009. Retrieved January 17, 2015 from http://www.zav-zdruzenje.si/wp-content/uploads/2012/11/Statisticni-zavarovalniski-bilten-2009. pdf.
SIA - Slovenian Insurance Association. Statistical Insurance Bulletin 2013. 2013. Retrieved August 21, 2013 from http://www.zav-zdruzenje.si/portfolio/ statisticni-zavarovalniski-bilten-2013/.

SIA - Slovenian Insurance Association. Statistical Insurance Bulletin 2014. 2014. Retrieved January 19, 2015 from http://www.zav-zdruzenje.si/wp-content/uploads/2014/07/Statisticni-zavarovalniski-bilten-2014. pdf.

Siddiqui, M.H., Sharma, T.G. 2010. Measuring the Customer Perceived Service Quality for Life Insurance Services: An Empirical Investigation. International Business Research 3 (3): 171-186.

Šebjan, U., Bastič, M. 2013. Service Components and Their Importance in Health Insurance Changes. Naše gospodarstvo 59 (3-4): 14-25.

Tsao, Y.-C., Sheen, G.-J. 2012. Effects of promotion cost sharing policy with the sales learning curve on supply chain coordination. Computers \& Operations Research 39 (8): 1872-1878.

Ulbinaite, A., Kucinskiene, M. 2013. Insurance service purchase decision-making rationale: expert-based evidence from Lithuania. Ekonomika 9 (2): 137-155.

Vaughan, E.J., Vaughan, T.M. 2008. Fundamentals of Risk and Insurance. John Wiley \& Sons: Hoboken.

de Vaus, D.A. 1995. Surveys in Social Research, 4th ed. Allen and Unwin Pty Ltd: Sydney.

Verma, H.V. 2012. Services Marketing. New Delhi: Person Education.

Walker, J., Baker, J. 2000. An exploratory study of a multiexpectation framework for services. Journal of Services Marketing 14 (5): 411-431.

Walsh, G., Shiu, E., Hassan, L.M. 2013. Replicating, validating, and reducing the length of the consumer perceived value scale. Journal of Business Research 31 May: 1-8.

Ward, D., Zurbruegg, R. 2000. Does Insurance Promote Economic Growth? Evidence from OECD Countries. The Journal of Risk and Insurance 67 (4): 489-507.

Weng, J.T., de Run, E.C. 2013. Consumers' personal values and sales promotion preferences effect on behavioural intention and purchase satisfaction for consumer product. Asia Pacific Journal of Marketing and Logistics 25 (1): 70-101.

Williams, C.A., Smith, M.L., Young, P.C. 1998. Risk Management and Insurance. Boston: Irwin/McGraw-Hill.

Yoo, D.K., Park, J.A. 2007. Perceived service quality. Analyzing relationships among employees, customers, and financial performance. International Journal of Quality \& Reliability Management 24 (9): 908-926.

Zeithaml, V.A., Bitner, M. 2000. Service Marketing. McGrawHill: New York.

Zweifel, P., Eisen, R. 2012. Insurance Economics. Springer: Berlin. 